\title{
Granulomatous polyangitis (Wegener granulomatosis): Clinical findings and results of long-term follow-up
}

\author{
Nazan ŞEN ${ }^{1}$ \\ Müge AYDIN TUFAN ${ }^{2}$ \\ Reyhan YILDIZ ${ }^{3}$ \\ Emine Duygu ERSÖZLÜ \\ BOZKIRLI ${ }^{4}$ \\ Eftal YÜCEL ${ }^{5}$
}

${ }^{1}$ Department of Chest Diseases, Baskent University Adana Dr. Turgut Noyan Teaching and Medical Research Center, Adana, Turkey

${ }^{1}$ Başkent Üniversitesi Adana Dr. Turgut Noyan Uygulama ve Araştırma Merkezi, Göğüs Hastalıkları Anabilim Dalı, Adana, Türkiye

2 Division of Rheumatology, Department of Internal Medicine, Baskent University Adana Dr. Turgut Noyan Teaching and Medical Research Center, Adana, Turkey

${ }^{2}$ Başkent Üniversitesi Adana Dr. Turgut Noyan Uygulama ve Araştırma Merkezi, iç Hastalıkları Anabilim Dalı, Romatoloji Bilim Dalı, Adana, Türkiye

${ }^{3}$ Clinic of Chest Diseases, Istanbul Sureyyapasa Chest Diseases and Chest Surgery Training and Research Hospital, Istanbul, Turkey

3 İstanbul Süreyyapaşa Göğüs Hastalıkları ve Göğüs Cerrahisi Eğitim ve Araştırma Hastanesi, Göğüs Hastalıkları Kliniği, İstanbul, Türkiye

${ }^{4}$ Clinic of Rheumatology, Adana Numune Training and Research Hospital, Adana, Turkey

${ }^{4}$ Adana Numune Eğitim ve Araştırma Hastanesi, Romatoloji Kliniği, Adana, Türkiye

${ }^{5}$ Division of Rheumatology, Department of Internal Medicine, Faculty of Medicine, Baskent University, Ankara, Turkey

${ }^{5}$ Başkent Üniversitesi Tıp Fakültesi, lç Hastalıkları Anabilim Dalı, Romatoloji Bilim Dalı, Ankara, Türkiye

\section{SUMMARY}

Granulomatous polyangitis (Wegener granulomatosis): clinical findings and results of long-term follow-up

Introduction: To evaluate long-term outcome of patients with granulomatous polyangitis (GPA) followed up in a tertiary university hospital.

Patients and Methods: We reviewed medical records of 22 patients with GPA diagnosis confirmed by tissue biopsies between 2004 and 2014.

Results: The mean time from the onset of symptoms to diagnosis was $7.8 \pm 12.3$ months [interquartile range $(I R)=4.0$ ]. The most commonly involved organs were the upper respiratory tract (URT) (72.7\%), lower respiratory tract (81.8\%) and kidneys (72.7\%). URT involvement indicated good prognosis $(p=0.046)$. Survival in the patients with and without URT involvement was $124.6 \pm$ 6.9 months and $59.7 \pm 22.9$ months, respectively. End-stage renal failure (ESRF) requiring dilaysis and cardiac involvement were associated with mortality ( $p=0.022$ and $p=0.026$, respectively). Of the 12 dialysis-dependent patients at diagnosis, 11 survived > 3 months and seven regained renal function permanently. Dialysis dependency was significantly lower in patients who received plasmapheresis $(p=0.047)$. Overall mortality rate was $18 \%$ (4/22). Mean survival was $55.9 \pm 42.8$ months $(I R=84.0)$.

\section{Yazış̧ma Adresi (Address for Correspondence)}

Dr. Nazan ŞEN

Başkent Üniversitesi Adana Dr. Turgut Noyan Uygulama ve Araştırma Merkezi, Göğüs Hastalıkları Anabilim Dalı, ADANA - TURKEY

e-mail: nazansen68@gmail.com 
Conclusion: Diagnosis of GPA may be delayed by the nonspecific nature of its symptoms. URT involvement was associated with good prognosis, whereas cardiac involvement and ESRF requiring dialysis were associated with poor outcome. Plasmapheresis may increase the rate of renal recovery in the patients with ESRF requiring dialysis.

Key words: Granulomatosis polyangitis, outcome, vasculitis, Wegener granulomatosis

\section{ÖZET}

\section{Granülomatöz polianjit (Wegener granülomatozis): Klinik bulgular ve uzun dönem izlem sonuçları}

Giriş: Üçüncü basamak bir üniversite hastanesinde granülomatöz polianjit (GPA) tanılı hastaların uzun dönem izlem sonuçlarının değerlendirilmesi.

Materyal ve Metod: Hastanemizde 2004-2014 tarihleri arasında, tanısı doku biyopsileri ile doğrulanmış 22 GPA'lı hastanın medikal kayıtları incelendi.

Bulgular: Semptomların başlangııından tanıya kadar geçen süre $7.8 \pm 12.3$ ay [interquartile range $(I R)=4.0$ ] olarak bulundu. En sık tutulan organlar üst solunum yolu (ÜSY) (\%72.7), alt solunum yolu (\%81.8) ve böbreklerdi (\%72.7). ÜSY tutulumu iyi prognoz göstergesiydi $(p=0.046)$. Sağkalım süresi ÜSY tutulumu olan ve olmayan hastalarda sırasıly $124.6 \pm 6.9$ ay ve $59.7 \pm 22.9$ aydı. Diyaliz gerektiren son dönem böbrek yetmezlĭgi (SDBY) ve kardiyak tutulum mortalite ile ilişkili bulundu (sırasıyla $p=0.022$ ve $p=0.026$ ). Tanı sırasında diyalize bağımlı 12 hastanın 11'i 3 aydan uzun süre yaşadı ve bunların 7'sinde böbrek fonksiyonları kalıcı olarak düzeldi. Plazmaferez uygulanan hastalarda diyaliz bağımlılığı anlamlı olarak düşüktü ( $p=0.047)$. Toplam mortalite oranı \% 18 (4/22) olarak bulundu. Ortalama sağkalım $55.9 \pm 42.8$ aydı $(I R=84.0)$.

Sonuç: Hastalığın nonspesifik semptomları nedeniyle GPA tanısında gecikmeler yaşanabilmektedir. Çalışmamızda ÜSY tutulumu iyi prognoz göstergesi olarak bulunurken, kardiyak tutulum ve diyaliz gerektiren SDBY kötü prognoz ile ilişkili bulundu. Plazmaferez diyaliz gerektiren SDBY'li hastalarda iyileşme hızını artırabilir.

Anahtar kelimeler: Granülomatöz polianjit, sonuçlar, vaskülit, Wegener granülomatozisi

\section{INTRODUCTION}

Wegener granulomatosis was first defined in 1936 by Friedrich Wegener but has been known as granulomatous polyangitis (GPA) since 2011. It is a form of vasculitis that is associated with antineutrophilic cytoplasmic antibody (ANCA). Clinical signs of GPA are variable and may involve many organs; most commonly, the upper respiratory truct (URT), lower respiratory tract, and kidneys. Although its etiology remains unclear, it is thought to occur due to infectious, environmental, chemical, toxic and pharmacological stimulation in individuals who are prone to autoimmune diseases. The diagnosis is based on clinical findings, ANCA positivity, and appropriate histopathological findings (1).

Prompt diagnosis and treatment are important in preventing mortality and/or permanent organ damage. Remission occurs in $85 \%-90 \%$ of treated patients (2). Despite current advances in diagnosis and treatment, relapse and refractory disease remain as challenges (3). Relapse rate within 5 years is $\sim 50 \%$ (4).

The present study aimed to investigate clinical and laboratory characteristics of GPA in patients followed for 11 years in a tertiary university hospital, as well as the results of long-term follow-up and survival, and related factors.

\section{MATERIALS and METHODS}

We enrolled 22 patients who were diagnosed with GPA based on the American Rheumatology College (ACR) 1990 criteria between 2004 and 2014 in Baskent University Adana Dr. Turgut Noyan Teaching and Medical Research Center. Patient information was obtained from the medical records, which included all necessary clinical, laboratory and pathological data. The diagnosis was confirmed by tissue biopsy in all patients.

The cases were evaluated in terms of demographic characteristics, clinical and laboratory findings, time to diagnosis, diagnostic methods, sites of organ involvement, Birmingham Vascular Activity Score (BVAS) and Vascular Damage Index (VDI) at diagnosis, treatment approaches, follow-up duration, and long-term disease progression. ANCA tests were performed in the same laboratory using indirect immunofluorescence.

A follow-up protocol was used in 21 patients. The remaining one patient died at diagnosis before the treatment is started. Patients received baseline therapy as inpatients. After achieving complete or partial remission, they were regularly followed in outpatient clinics. First-line treatment consisted of combined methylprednisolone and cyclophosphamide (CYC). 
Pulse methylprednisolone therapy was started at a dose of $500 \mathrm{mg} /$ day for 3-5 days depending on disease activity. Subsequently, treatment continued with prednisolone at a dose of $1 \mathrm{mg} / \mathrm{kg} /$ day. It was targeted to reduce corticosteroid dose to $15-20 \mathrm{mg} /$ day within 3-4 months. Simultaneously, intravenous CYC was commenced at a dose of $500 \mathrm{mg} /$ day at 2-week intervals for the first 3 months and then continued every 4-6 weeks depending on disease activity. After 2011, patients with refractory disease and serious disease activity received an additional $1 \mathrm{~g}$ rituximab (RTX) (an anti-CD20 monoclonal antibody) every 6 months on two occasions at 2-week intervals. Plasmapheresis was performed 7-10 times in cases with serious renal injury and alveolar hemorrhage. Maintenance therapy was started within 12-18 months in the patients with remission. This consisted of azathioprine (AZA), methotrexate (MTX) or mycophenolate mofetil (MMF). The dose of methylprednisolone was increased in the patients that developed relapse and combined with CYC or RTX; frequency of administration was increased in the patients already receiving CYC. All patients that received CYC and RTX also received trimethoprimsulfamethoxazole therapy 3 days a week for prophylaxis of Pneumocystis jirovecii infection.

\section{Statistical Analysis}

Statistical analysis was performed using SPSS version 17.0 (SPSS Inc., Chicago, IL, USA). Continuous variables were presented as mean \pm standard deviation [ $p>0.05$ in Kolmogorov-Smirnov or Shapiro-Wilk test $(n<30)]$ if they showed a normal distribution, whereas they were presented as median if they were not distributed normally. Continuous variables were compared using Mann-Whitney $U$ test depending on non-parametric values. The categorical variables were compared between the groups using the chisquare test or Fisher's exact test. The level of statistical significance was predetermined as $p<0.05$.

\section{RESULTS}

Baseline data at diagnosis for 22 GPA patients are shown in Table 1 . There were nine female and 13 male patients, with a mean age at diagnosis of $47.0 \pm$ $10.9(\mathrm{IR}=17.0)$ years. The longest follow-up period was 132 months and the last patient was enrolled 2 months before the completion of study. The mean time to diagnosis was $7.8 \pm 12.3$ ( $I R=4.0)$ months and the mean follow-up duration was $42.9 \pm 39.9$ $(\mathrm{IR}=74.0)$ months. The most commonly involved sites were the lungs $(18,81.8 \%)$, URT $(16,72.7 \%)$ and
Table 1. Demographic, clinical and serological chanracteristics of the patients at diagnosis

\begin{tabular}{|lc|}
\hline Parameters & Values \\
\hline Sex (F/M) & $9 / 13$ \\
Age at diagnosis (years) & $47.0 \pm 10.9(\mathrm{IR}=17.0)$ \\
Time to the diagnosis (months) & $7.8 \pm 12.3(4.0)$ \\
Follow-up duration (months) & $42.9 \pm 39.9(\mathrm{IR}=74.0)$ \\
Survival (months) & $55.9 \pm 42.8(\mathrm{IR}=84.0)$ \\
Constitutional symptoms, $\mathrm{n}(\%)$ & $21(95.5)$ \\
Lungs, $\mathrm{n}(\%)$ & $18(81.8)$ \\
Upper respiratory tract, $\mathrm{n}(\%)$ & $16(72.7)$ \\
Kidneys, $\mathrm{n}(\%)$ & $16(72.7)$ \\
Eyes, $\mathrm{n}(\%)$ & $4(18.2)$ \\
Mucous membrane, $\mathrm{n}(\%)$ & $4(18.2)$ \\
Skin, $\mathrm{n}(\%)$ & $4(18.2)$ \\
Musculoskeletal, $\mathrm{n}(\%)$ & $13(59.1)$ \\
Nervous system, $\mathrm{n}(\%)$ & $4(18.2)$ \\
Cardiovascular system, $\mathrm{n}(\%)$ & $2(9.1)$ \\
Breasts, $\mathrm{n}(\%)$ & $1(4.5)$ \\
Gastrointestinal system, $\mathrm{n}(\%)$ & $2(9.1)$ \\
Alveolar hemorrhage, $\mathrm{n}(\%)$ & $6(27.3)$ \\
Renal failure, $\mathrm{n}(\%)$ & $12(54.5)$ \\
Upper respiratory tract + & $9(40.9)$ \\
lungs + kidneys, $\mathrm{n}(\%)$ & \\
ESR, mm/h & $93 \pm 26(\mathrm{IR}=35.0)$ \\
Creatinine, mg/dL & $4.5 \pm 3.8(\mathrm{IR}=7.02)$ \\
Creatinine clearance & $383.8(\mathrm{IR}=620.5)$ \\
c-ANCA positivity, $\mathrm{n}(\%)$ & $\pm 6.1(\mathrm{IR}=9.0)$ \\
BVAS score & $2.0(\mathrm{IR}=3.0)$ \\
VDI score & \\
\hline & \\
\hline
\end{tabular}

kidneys (16, 72.7\%). There were nine cases with the classical triad of GPA: combination of URT and lower respiratory tract and renal involvement. Six cases developed alveolar hemorrhage. Of the 12 patients that required dialysis at baseline, 11 survived $>3$ months and 7 discontinued dialysis over the course of follow-up. Although one patient died shortly after hemodialysis was started (day 15 of diagnosis), hemodialysis was continued throughout the follow-up period in the remaining four patients ( 3 hemodialysis, 1 peritoneal dialysis). Cardiac involvement was seen in two cases as mitral valve disease and heart failure.

With regard to the baseline laboratory analysis, erythrocyte sedimentation rate (ESR), creatinine values and creatinine clearances were $93.7 \pm 26.8$ $(\mathrm{IR}=35.0) \mathrm{mm} / \mathrm{s}$ and $4.5 \pm 3.8(\mathrm{IR}=7.02) \mathrm{mg} / \mathrm{dL}$, and $382.7 \pm 343.8(I R=620.5)$, respectively. No significant 
correlation was demonstrated between these laboratory parameters and mortality. Cytoplasmic-ANCA (c-ANCA) was positive in 19 patients, whereas perinuclear-ANCA (p-ANCA) was positive in five. p-ANCA was positive in all three cases with negative c-ANCA results. The mean BVAS score was $19.3 \pm 6.1$ (IR=9.0), and no correlation was shown with mortality. The mean VDI score was $3.9 \pm 2.0(I R=3.0)$, and there was no significant correlation between surviving and deceased patients $(3.6 \pm 2.0$ and $5.5 \pm 1.0$, respectively; $\mathrm{p}<0.081)$.

No radiological pulmonary pathology was detected in four cases. The most common radiological finding was cavitary ( 7 cases)/non-cavitary ( 7 cases) nodular mass lesions. Ground glass opacity was observed in eight and consolidation was observed in four cases, whereas pleural thickening was observed in one.

Four patients (18.2\%) stopped follow-up visits. Information that these cases were alive was obtained via telephone call or from the central recording system. Of the 17 patients that continued follow-up over the course of their treatment, eight completed follow-up without relapse. Relapse developed in nine cases [ $(53 \%)$; in the lungs in 5 patients and in the kidneys in 4]. Refractory disease was seen in one case.

Tretament regimens of 21 patients are demonstrated in Table 2. Initially, all patients received methylprednisolone and CYC. Complete remission could not be achieved in four patients. These patients received RTX in addition to CYC. No adverse events that require discontinuation of intravenous $\mathrm{CYC}$ administration occurred over the course of treatment. None of the patients developed hemorrhagic cystitis, bladder carcinoma, severe immunesuppression or leukopenia over the course of follow-up. Plasmapheresis as induction therapy was performed in six patients. Of these patients, four had end-stage renal failure (ESRF) requiring dialysis, one had ESRF requiring dialysis together with alveolar hemorrhage, and one had only alveolar hemorrhage. It was observed that all the five patients that underwent plasmapheresis regained renal functions, and remained dialysis free for their follow-up period. Maintenance therapy including AZA (15 patients, $2-2.5 \mathrm{mg} / \mathrm{kg} /$ day), MTX (1 patient, $15 \mathrm{mg} /$ week) or MMF (1 patient, 2 g/day) was started in the patients that developed remission within 12-18 months. Relapse occurred in nine patients. Either the dose of methylprednisolone was increased or pulse IV methylprednisolone (500-1000 $\mathrm{mg} /$ day, 3-5 days) therapy was administered in these patients. They also received CYC (7 patients) or RTX (2 patients) in addition to methylprednisolone.

During follow-up, one case developed chronic lymphocytic leukemia together with non-Hodgkin's lymphoma, one developed pulmonary tuberculosis, and another developed $P$. jirovecii pneumonia. Hepatitis $B$ reactivation occurred in one patient receiving RTX. One case (with refractory disease) underwent surgery for pneumothorax and prolonged air leak. A total of four cases died. Cause of death was sepsis in two cases (the source was wound site infection in one and peritonitis in the other), whereas the remaining two cases died from GPA. One of these patients, who died on day 15 of hospitalization, had ESRF requiring dialysis, alveolar hemorrhage with pulmonary involvement, and URT involvement. The other case died due to recurrent disease.

No significant relation was determined between renal or pulmonary involvement and prognosis. URT involvement indicated good prognosis (Figure 1A); however, ESRF requiring hemodialysis (Figure 1B) and cardiac involvement showed a significant cor-

Table 2. Treatment regimen of 21 patients with granulomatous with polyangitis

\begin{tabular}{|c|c|c|c|}
\hline & $\begin{array}{l}\text { Induction of remission } \\
\text { n (\%) }\end{array}$ & $\begin{array}{l}\text { Maintenance therapy } \\
\text { n (\%) }\end{array}$ & $\begin{array}{c}\text { Relapse therapy } \\
\text { n }(\%)\end{array}$ \\
\hline $\begin{array}{l}\text { CYC (IV); } 500 \mathrm{mg} / \text { day at } 2 \text { weeks intervals for the first } \\
3 \text { months, and then continued every } 4-6 \text { weeks }\end{array}$ & $21(100)$ & - & $7(33)$ \\
\hline AZA; $2-2.5 \mathrm{mg} / \mathrm{kg} /$ day & - & $15(71)$ & - \\
\hline MTX; 15 mg/week & - & $1(4)$ & - \\
\hline MMF; 2 g/day & - & $1(4)$ & - \\
\hline $\begin{array}{l}\text { RTX; } 1 \mathrm{~g} \text { /day every } 6 \text { months on two } \\
\text { occasions at } 2 \text {-week intervals }\end{array}$ & $4(19)$ & - & $2(9)$ \\
\hline Plasmapheresis & $6(28)$ & - & - \\
\hline
\end{tabular}




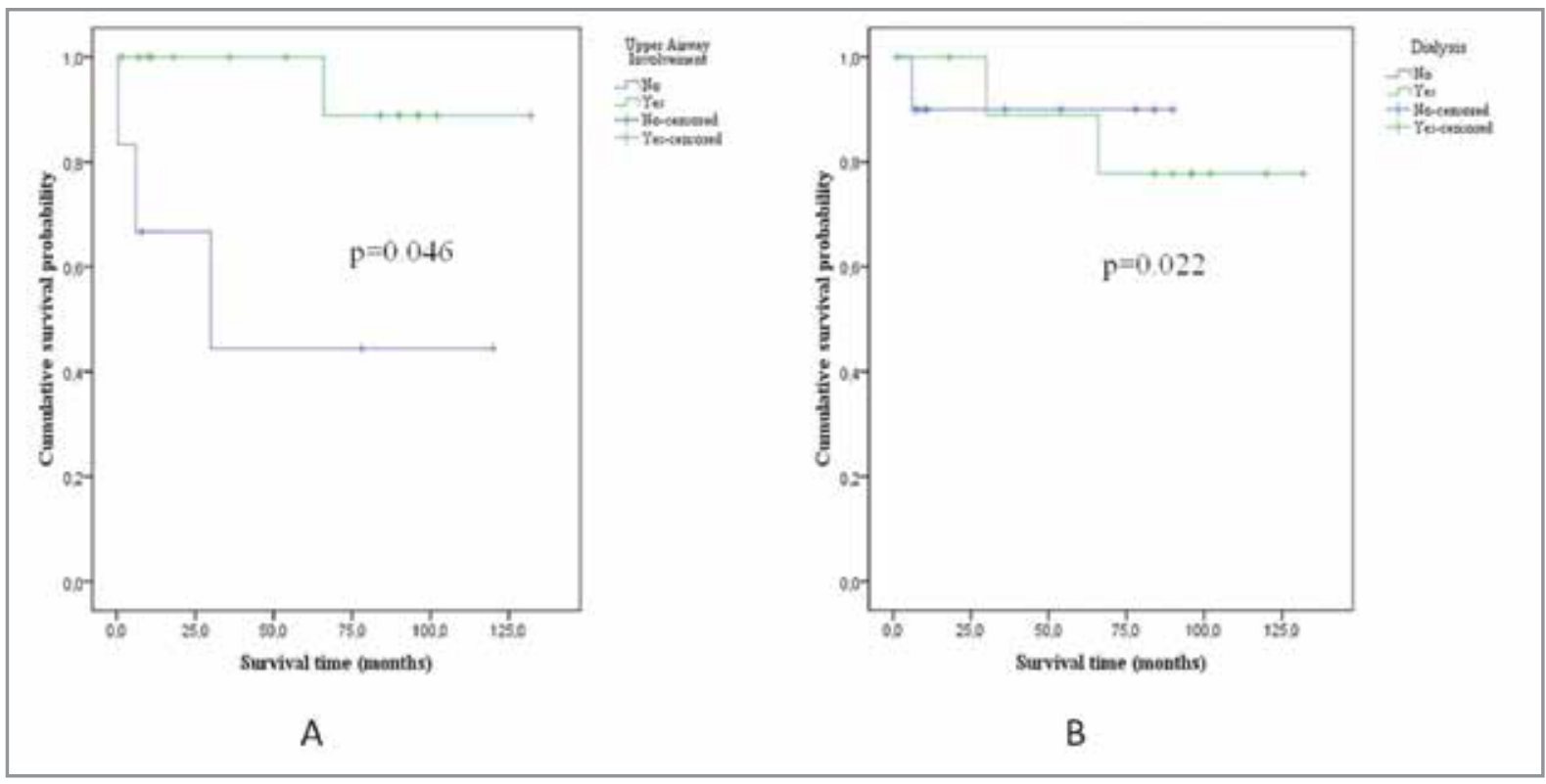

Figure 1. Survival time (A) in patients with upper respiratory tract involvement and (B) with end-stage renal failure requiring hemodialysis.

relation with mortality $(\mathrm{p}=0.046, \mathrm{p}=0.022$, and $\mathrm{p}=$ 0.026 , respectively). The prevalence of permanent dialysis was significantly lower in the patients that underwent plasmapheresis versus those did not $(p=0.047)$.

Two-, 5- and 11- year overall survival rates were $91 \%, 86 \%$ and $82 \%$, respectively. Mean survival was $55.9 \pm 42.8(I R=84.0)$ months. Survival analysis was performed, and estimated survival was $107.4 \pm 10.9$ months.

\section{DISCUSSION}

The present study comprised the results of 11 years follow-up of GPA patients with diagnosis confirmed by tissue biopsies in a single tertiary hospital. URT involvement was associated with good prognosis, whereas cardiac involvement and renal failure requiring dialysis were associated with poor prognosis. However, no relationship was demonstrated between any of the other demographic, clinical or biological parametres and patient survival. Among patients with ESRF requiring dialysis, prevalence of dialysis dependency was significantly lower in the patients who received plasmapheresis than in those who did not $(p<0.047)$. The mean follow-up period was 43 months with overall survival of $82 \%$. The estimated survival was $107.4 \pm 10.9$ months.
In different studies, time to diagnosis from the onset of symptoms was reported to be 4.5-10.3 months (5-8). Abdou et al. reported that only $22 \%$ of the patients were diagnosed in the first month after the onset of symptoms, whereas the diagnosis was made within 6-12 months in 15\% and after $>1$ year in 18\% of the patients (9). In the present study, mean time from the onset of symptoms to diagnosis was 7.8 months. This slightly longer period was attributed to delayed presentation of the patients to our hospital. There were 11 cases $(50 \%)$ diagnosed within 2 months; of which four (18\%) had been diagnosed within 1 month. Time to diagnosis was $>1$ year $(48$ months) in only one case. This case had isolated pulmonary involvement, which was first considered to be tuberculosis. Reinhold-Keller et al. and Takala et al. pointed out that a multidisciplinary approach may reduce diagnostic delay in patients with suspicion of systemic vasculitis $(10,11)$.

GPA is a potentially fatal disease with a life expectancy of 5 months in untreated patients. One- and 2 - year mortality rates were $80 \%$ and $93 \%$, respectively (12). Concurrent use of CYC and corticosteroid therapy resulted in a rapid decrease in mortality $(10,12,13)$, and 10-year survival rates reached to $75 \%-88 \%(7,10)$. In the present study, four cases died during follow-up and 11-year survival rate was found to be $82 \%$. Most of our cases (91\%) lived longer than 1 year. However, Mahr et al. described lower survival 
rate $(67.5 \%$ for 2 -years) for GPA patients in his prospective, multicenter study (14). Selected patient population and nature of the studies may have contributed to the differences in survival rates. Mortality rates varied between $14 \%$ and $41 \%$ in different studies (5-7, 10,14-16). In an early study from Turkey (2005), mortality rate was $41 \%$ in a mean 36 -month follow-up period, and this higher rate of mortality was found to be related to the initial organ damage (6). A later study from Turkey (2010) determined the mortality rate to be $20 \%$ in a mean 45 -month follow-up period (15). In the present study, mortality rate was $18 \%$ in a mean 43-month follow-up period. Reduction in mortality rates over the years, in our country, may be associated with increased awareness about the disease, enhanced diagnostic facilities, and the use of effective treatment methods.

Current strategy for induction of remission includes the use of high-dose corticosteroid together with CYC or RTX. Plasmapheresis can be performed in the patients with life-threatening organ involvement. RTX and CYC were compared in two large-scale studies $(17,18)$ in the literature. While RAVE (Rituximab in Anti-neutrophil Cytoplasmic Antibody-Associated Vasculitis) study failed to demonstrate superiority of RTX to CYC in the induction of remission, better outcomes were obtained with RTX in relapse disease (17). In the RITUXVAS study of The European Vasculitis Study Group (EUVAS), it was expressed that RTX is not superior to CYC but effective in the induction of remission (18). No difference was determined between the two drugs in terms of adverse events in either study. In the present study, RTX was used for the induction of remission in four and for relapse in two patients. The number of patients was not adequate to statistically compare the efficacy of CYC and RTX. Remission was achieved in all but one of the patients receiving RTX.

The protective effect of URT involvement in GPA was demonstrated in some studies $(5,14,19)$. Luqmani et al. determined better prognosis in non-renal GPA patients, in whom URT involvement was more prevelant (19). In addition, two other studies suggested that the presence of URT disease may be associated with better outcome, which has been supported by the results of the present study $(5,14)$. Relapse rate was reported to be higher in the patients with URT involvement (20). In the present study, the relapse rate was $41 \%$ and URT disease was detected in all patients that developed relapse.
Although the effect of pulmonary involvement on survival has not been demonstrated in the majority of studies $(6,7,14,16)$, Reinhold-Keller et al. reported that patients without pulmonary involvement live longer, independent of age and time to diagnosis (10). We were unable to show any effect of pulmonary involvement and alveolar hemorrhage on survival.

Renal involvement may present with different symptoms and signs including hematuria, proteinuria, elevated creatinine level, and ESRF. The fact that renal involvement is a determinant of poor prognosis was demonstrated for the first time by Carrington and Liebow (21). This finding was supported by Luqmani et al. (19) However, the relation of renal involvement with poor prognosis could not be demonstrated in the present study, as it was in some other studies $(7,16)$. Nevertheless, confirming some earlier studies $(6,7,14,22)$, ESRF requiring dialysis was a significant risk factor for mortality. ESRF requiring dialysis was a better determinant than serum creatinine level in the present study. Renal function was recovered in $64 \%$ $(7 / 11)$ of the cases that received dialysis at baseline. Hence, the presence of ESRF requiring dialysis at baseline does not indicate permanent renal injury. It has been demonstrated that addition of plasmapheresis to corticosteroids and CYC therapy, in the presence of renal failure, is associated with higher rates of renal recovery and dialysis independency in the first year (23). It probably has no effect on mortality or long-term renal functions (23). In the present study, there was a significant relation between plasmapheresis and dialysis dependency. Dialysis independency developed in five, all of whom had received plasmapheresis, of the 11 patients that required dialysis at baseline and survived $>3$ months. Dialysis was continued throughout the follow-up period in the four ( 3 hemodialysis, 1 peritoneal dialysis) of remaining six patients.

There was a significant increase in mortality in the patients with cardiac involvement $(p<0.026)$. One of the two patients with cardiac involvement died after 6 months and the other after 5.5 months follow-up. One prior study demonstrated a significant relation between cardiac involvement and survival, but another two studies did not $(5,7,10)$.

The present study had several limitations. Patient data until the last 4 years were obtained retrospectively from medical records. Despite the fact that patient records included necessary clinical, laboratory and pathological data, there may have been some inade- 
quacy because BVAS and VDI scores were retrospectively calculated based on the records. Treatmentrelated complications could not be assessed completely because of limited data. Nevertheless, nonrandomized treatments might have unfavorably influenced our results.

In conclusion, diagnosis of GPA may be delayed by the nonspecific nature of its symptoms. URT involvement was associated with good prognosis, whereas cardiac involvement and ESRF requiring dialysis were associated with poor outcome. The present study supports the use of plasmapheresis in GPA patients with ESRF requiring dialysis.

\section{CONFLICT of INTEREST}

None declared.

\section{REFERENCES}

1. Lutalo PM, D'Cruz DP. Diagnosis and classification of granulomatosis with polyangiitis (aka Wegener's granulomatosis). J Autoimmun 2014;48-49:94-8.

2. Miloslavsky EM, Specks U, Merkel PA, Specks U, Merkel PA, Seo $P$, et al. Clinical outcomes of remission induction therapy for severe antineutrophil cytoplasmic antibody-associated vasculitis. Arthritis Rheum 2013;65:2441-9.

3. Mubashir E, Ahmed MM, Hayat S, Latif S, Heldmann M, Berney SM. Wegener granulomatosis: a case report and update. South Med J 2006;99:977-88.

4. Pagnoux C, Hogan SL, Chin H, Jennette JC, Falk RJ, Guillevin $L$, et al. Predictors of treatment resistance and relapse in antineutrophil cytoplasmic antibody-associated small-vessel vasculitis: comparison of two independent cohorts. Arthritis Rheum 2008;58:2908-18.

5. Lane SE, Watts RA, Shepstone L, Scott DG. Primary systemic vasculitis: clinical features and mortality. $Q$ I Med 2005;98:97-111.

6. Kamali S, Inanc M, Gul A, Ocal L, Polat NG, Kilicaslan I, et al. Systemic necrotizing vasculitides in Turkey: a comparative analysis of 40 consecutive patients. Rheumatol Int 2005;26:16-20.

7. Koldingsnes $W$, Nossent H. Predictors of survival and organ damage in Wegener's granulomatosis. Rheumatology 2002;41:572-81.

8. Ozbalkan Z, Kiraz S, Ozturk MA, Ertenli Al, Apras S, Calguneri M. Wegener's granulomatosis: clinical and laboratory results of a university hospital study of 20 patients from Turkey. Clin Rheumatol 2006;25:358-63.

9. Abdou NI, Kullman GJ, Hoffman GS, Sharp GC, Specks U, McDonald T, et al. Wegener's granulomatosis: survey of 701 patients in North America. Changes in outcome in the 1990s. J Rheumatol 2002;29:309-16.
10. Reinhold-Keller E, Beuge N, Latza U, de Groot K, Rudert H, Nölle $B$, et al. An interdisciplinary approach to the care of patients with Wegener's granulomatosis: long-term outcome in 155 patients. Arthritis Rheum 2000;43:1021-32.

11. Takala $J H$, Kautiainen $H$, Malmberg H, Leirisalo-Repo M. Wegener's granulomatosis in Finland in 1981-2000: clinical presentation and diagnostic delay. Scand I Rheumatol 2008;37:435-8.

12. Walton EW. Giant-cell granuloma of the respiratory tract (Wegener's granulomatosis). Br Med J 1958;2:265-70.

13. Hogan SL, Nachman PH, Wilkman AS, Jennette JC, Falk RJ. Prognostic markers in patients with antineutrophil cytoplasmic autoantibody-associated microscopic polyangiitis and glomerulonephritis. J Am Soc Nephrol 1996; 7:23-32.

14. Mahr A, Girard T, Agher R, Guillevin L. Analysis of factors predictive of survival based on 49 patients with systemic Wegener's granulomatosis and prospective follow-up. Rheumatology 2001;40:492-8.

15. Kamali S, Erer B, Artim-Esen B, Gul A, Ocal L, Konice M, et al. Predictors of damage and survival in patients with Wegener's granulomatosis: analysis of 50 patients. I Rheumatol 2010;37:374-8.

16. Dadoniene I, Pileckyte M, Baranauskaite A, Kirdaite G. Clinical characteristics and long-term outcomes of 35 patients with Wegener's granulomatosis followed up at two rheumatology centers in Lithuania. Medicina 2010;46:256-60.

17. Stone JH, Merkel PA, Spiera R, Seo P, Carol A. Langford, et al. Rituximab versus Cyclophosphamide for ANCAAssociated Vasculitis. N Engl I Med 2010;363:221-32.

18. Jones RB, Tervaert $N$, Hauser T, Luqmani R, Morgan MD, Peh $C A$, et al. Rituximab versus Cyclophosphamide in ANCAAssociated Renal Vasculitis. N Engl I Med 2010;363:211-20.

19. Luqmani RA, Bacon PA, Beaman M, Scott DG, Emery $P_{1}$ Lee $S$, et al. Classical versus non-renal Wegener's granulomatosis. Q J Med 1994;87:161-7.

20. Hogan SL, Falk RJ, Chin H, Cai J, Jennette CE, Jennette JC, et al. Predictors of relapse and treatment resistance in antineutrophil cytoplasmic antibody-associated small-vessel vasculitis. Ann Intern Med 2005;143:621-31.

21. Carrington CB, Liebow A. Limited forms of angiitis and granulomatosis of Wegener's type. Am J Med 1966;41:497527.

22. Aasarød K, Iversen BM, Hammerstrøm J, Bostad L, Vatten L, Jørstad S. Wegener's granulomatosis: clinical course in 108 patients with renal involvement. Nephrol Dial Transplant 2000; 15:611-8.

23. Jayne DR, Gaskin G, Rasmussen N, Abramowicz D, Ferrario $F$, Guillevin L, et al; European vasculitis study group. Randomized trial of plasma exchange or high-dosage methylprednisolone as adjunctive therapy for severe renal vasculitis. J Am Soc Nephrol 2007;18:2180-8. 